\title{
Application of Electrocoagulation Process Using Iron and Aluminum Electrodes for Fluoride Removal from Aqueous Environment
}

\author{
EDRIS BAZRAFSHAN ${ }^{1}$, KAMAL ALDIN OWNAGH ${ }^{1}$, AND \\ AMIR HOSSEIN MAHVI ${ }^{2,3,4 *}$
}

${ }^{1}$ Health Promotion Research Center, Zahedan University of Medical Sciences, Zahedan, Iran

${ }^{2}$ School of Public Health, Tehran University of Medical Sciences, Tehran, Iran

${ }^{3}$ National Institute of Health Research, Tehran University of Medical Sciences, Tehran, Iran

${ }^{4}$ Center for Solid Waste Research, Institute for Environmental Research, Tehran University of Medical Sciences, Tehran, Iran

ahmahvi@yahoo.com

Received 19 December 2011; Accepted 21 February 2012

\begin{abstract}
Fluoride in drinking water above permissible level is responsible for human being affected by skeletal fluorosis. The present study was carried out to assess the ability of electrocoagulation process with iron and aluminum electrodes in order to removal of fluoride from aqueous solutions. Several working parameters, such as fluoride concentration, $\mathrm{pH}$, applied voltage and reaction time were studied to achieve a higher removal capacity. Variable concentrations $\left(1,5\right.$ and $\left.10 \mathrm{mg} \mathrm{L}^{-1}\right)$ of fluoride solutions were prepared by mixing proper amount of sodium fluoride with deionized water. The varying $\mathrm{pH}$ of the initial solution (3, 7 and 10) was also studied to measure their effects on the fluoride removal efficiency. Results obtained with synthetic solution revealed that the most effective removal capacities of fluoride could be achieved at $40 \mathrm{~V}$ electrical potential. In addition, the increase of electrical potential, in the range of 10-40 V, enhanced the treatment rate. Also comparison of fluoride removal efficiency showed that removal efficiency is similar with iron and aluminum electrodes. Finally it can be concluded that the electrocoagulation process has the potential to be utilized for the costeffective removal of fluoride from water and wastewater.
\end{abstract}

Keywords: Fluoride removal, Electrocoagulation, Aqueous environment. 


\section{Introduction}

Fluoride in drinking water is usually the main source of fluoride intake, and excessive consumption of fluoride can cause a wide range of adverse health effects such as thyroid disorder, neurological damage, mottling of teeth, and fluorosis of skeleton. ${ }^{(1-7)}$ Also, the role of fluoride in reducing the risk of dental caries, especially among children, is well recognized. ${ }^{(8)}$ The suitable level of fluoride in drinking water specified by the World Health Organization (WHO) is $1.5 \mathrm{mg} \mathrm{L}^{-1}$. (9)

Many investigations have reported the fluoride content of air, ${ }^{(10)}$ groundwater, ${ }^{(11-12)}$ drinking water, ${ }^{(13)}$ bottled water, ${ }^{(14)}$ and some forms of black tea. ${ }^{(15)}$ During the past years, Electro-coagulation method has been proposed as an effective method to treat various wastewaters such as landfill leachate, restaurant wastewater, saline wastewater, tar sand and oil shale wastewater, urban wastewater, laundry wastewater, nitrate and arsenic bearing wastewater and chemical mechanical polishing wastewater. ${ }^{(16-18)}$

Electro-coagulation is a simple and efficient method to remove the flocculating agent generated by electro-oxidation of a sacrificial anode and generally made of iron or aluminum. In this process, the treatment is performed without adding any chemical coagulant or flocculants. Thus, reducing the amount of sludge which must be disposed. ${ }^{(19)}$ On the other hand, electrocoagulation is based on the in situ formation of the coagulant as the sacrificial anode corrodes due to an applied current, while the simultaneous evolution of hydrogen at the cathode allows for pollutant removal by flotation. This technique combines three main interdependent processes, operating synergistically to remove pollutants: electrochemistry, coagulation and hydrodynamics. An examination of the chemical reactions occurring in the electrocoagulation process shows that the main reactions occurring at the electrodes (aluminum and iron electrodes) are:

$$
\begin{gathered}
\mathrm{Al} \longleftrightarrow \mathrm{Al}^{3+}+3 \mathrm{e} \text { (anode) } \\
3 \mathrm{H}_{2} \mathrm{O}+3 \mathrm{e} \longleftrightarrow 3 / 2 \mathrm{H}_{2}+3 \mathrm{OH}^{-} \text {(cathode) }
\end{gathered}
$$

In addition, $\mathrm{Al}^{3+}$ and $\mathrm{OH}^{-}$ions generated at electrode surfaces react in the bulk wastewater to form aluminum hydroxide:

$$
\mathrm{Al}^{3+}+3 \mathrm{OH}^{-} \longleftrightarrow \mathrm{Al}(\mathrm{OH})_{3}
$$

Also the same chemical reactions occurring in the electrocoagulation process using iron electrodes:

$$
\begin{aligned}
& \longleftrightarrow \quad \mathrm{Fe}(\mathrm{s}) \quad \mathrm{Fe}^{+3} \mathrm{aq}+3 \mathrm{e}-\quad \text { (anode) } \\
& 3 \mathrm{H}_{2} \mathrm{O}+3 \mathrm{e}^{-} \longleftrightarrow 3 / 2 \mathrm{H}_{2} \mathrm{~g}+3 \mathrm{OH}^{-} \text {aq (cathode) } \\
& \mathrm{Fe}^{+3} \mathrm{aq}+3 \mathrm{OH}^{-} \mathrm{aq} \longleftrightarrow \mathrm{Fe}(\mathrm{OH})_{3}
\end{aligned}
$$

The aluminum and iron hydroxide flocs normally act as adsorbents and/or traps for metal ions. Therefore, they would eliminate them from the solution. ${ }^{(19)}$ The main purpose of this research was to investigate of the electrocoagulation process efficiency for fluoride removal from aqueous environments with iron and aluminum electrodes and determination of the effects of voltage, $\mathrm{pH}$, initial concentration of fluoride and reaction time on the removal efficiency. 


\section{Experimental}

At present study all chemicals including sodium fluoride $(\mathrm{NaF})$, concentrated sulfuric acid and potassium chloride were used as analytical grade. Variable concentrations (1, 5 and 10 $\mathrm{mg} \mathrm{L}^{-1}$ ) of fluoride solutions were prepared by mixing proper amount of sodium fluoride with deionized water. In order to increase the conductivity of the solution to $1.6 \mathrm{mS} \mathrm{Cm}^{-1}$, potassium chloride $(1 \mathrm{~N})$ was added to the solution before injecting it into the apparatus. The chloride salt added to the solution can also prevent the formation of the oxide layer on the anode and therefore reduce the passivation problem of the electrodes. The $\mathrm{pH}$ of initial solution was adjusted (3, 7 and 10) by using sulfuric acid solution and sodium hydroxide (0.1 M).

Experiments were performed in a bipolar batch reactor (figure 1), with four Aluminum and Iron electrode connected in parallel (bipolar mode). Only the outer electrodes were connected to the power source, and anodic and cathodic reactions occurred on each surface of the inner electrode when the current passed through the electrodes. The internal size of the cell was $10 \mathrm{Cm} \times 13 \mathrm{Cm} \times 12 \mathrm{Cm}$ (width $\times$ length $\times$ depth) with an effective volume of $1000 \mathrm{Cm}^{3}$. The volume $(\mathrm{V})$ of the solution of each batch was $1.0 \mathrm{~L}$. The active area of each electrode was $10 \times 10 \mathrm{Cm}$. The distance between electrodes was $1.5 \mathrm{Cm}$. A power supply pack having an input of $220 \mathrm{~V}$ and variable output of $0-40 \mathrm{~V}(10,20,30$ and $40 \mathrm{~V}$ for this study) with maximum current of 5 ampere was used as direct current source.

The temperature of each system was maintained at $25 \pm 1{ }^{\circ} \mathrm{C}$. The $\mathrm{pH}$ values in influent and reactor unit were measured using a pH meter model E520 (Metrohm Herisau, Switzerland). A Jenway Conductivity Meter (Model 4200) was employed to determine the conductivity of the solution. Different samples of $25 \mathrm{ml}$ were taken at $15 \mathrm{~min}$ intervals for up to $1 \mathrm{~h}$ and filtered before being analysed to determine the residual fluoride. The residual fluoride concentration was determined using fluoride electrode method according to the standard method. ${ }^{(20)}$

Magnetic stirring at $200 \mathrm{rpm}$ maintained a homogeneous solution in the batch reactor. Before and at the end of each run, the electrodes were washed thoroughly with water, dipped in $\mathrm{HCl}$ solution $(5 \% \mathrm{v} / \mathrm{v})$ for at least $15 \mathrm{~min}$ and rinsed again with tap water and finally weighted. All analyses were conducted in duplicate for reproducibility of data, and all of the data in the figures and tables were the average ones.

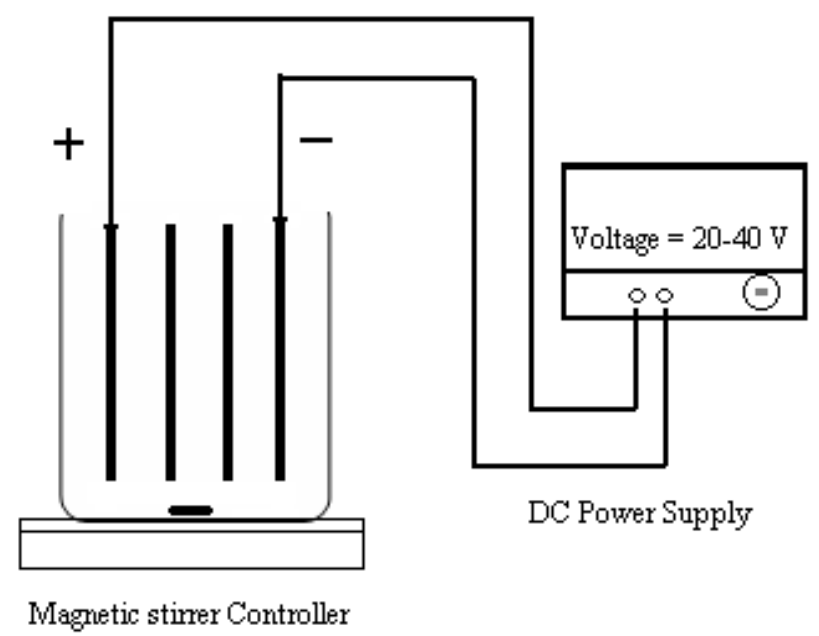

Figure 1. Set up of electrocoagulation system for fluoride removal. 


\section{Results and discussions}

The electrocoagulation process is quite complex and may be affected by several operating parameters, such as pollutants concentrations, initial $\mathrm{pH}$, electrical potential (voltage). In the present study, electrocoagulation process has been evaluated as a treatment technology for fluoride removal from synthetic solutions and fluoride removal efficiency at different condition $(\mathrm{pH}$, electrical potential and various initial concentrations) in various reaction times was evaluated.

\section{Effect of initial pH}

It has been established in previous studies ${ }^{(21,22)}$ that initial $\mathrm{pH}$ has a considerable effect on the efficiency of the electrocoagulation process. Also, as observed by other investigators the $\mathrm{pH}$ of the medium changed during the process depending on the type of electrode material and initial $\mathrm{pH}$. Meanwhile, EC process exhibits some buffering capacity, especially in alkaline medium, which prevents high changes in $\mathrm{pH}^{(23)}$ The results of this research showed that fluoride removal efficiency in alkaline conditions $(\mathrm{pH}=10)$ is better than acidic and neutral conditions.

In this study, the $\mathrm{pH}$ was varied in the range $3-10$ in an attempt to investigate the influence of this parameter on the removal of fluoride. Removal efficiencies of fluoride as a function of initial $\mathrm{pH}$ with iron and aluminum electrodes are presented in figures 2-13. As observed by other investigators, ${ }^{(24-26)}$ a $\mathrm{pH}$ increase occurs when the initial $\mathrm{pH}$ is low $(<7)$. Vik et al. ${ }^{(24)}$ ascribed this increase to hydrogen evolution at cathodes. However, this was contested by Chen et al. ${ }^{(27)}$, who explained this increase by the release of $\mathrm{CO}_{2}$ from wastewater owing to $\mathrm{H}_{2}$ bubble disturbance. Indeed, at low $\mathrm{pH}, \mathrm{CO}_{2}$ is over saturated in wastewater and can release during $\mathrm{H}_{2}$ evolution, causing a $\mathrm{pH}$ increase. In addition, if the initial $\mathrm{pH}$ is acidic, reactions would shift towards a $\mathrm{pH}$ increase. In alkaline medium $(\mathrm{pH}>$ 8 ), the final $\mathrm{pH}$ does not vary very much and a slight drop was recorded. Hence, the final $\mathrm{pH}$ of treated wastewater was nearly neutral which allows it to be directly discharged in natural aquatic streams. In this research, the influent $\mathrm{pH}$ did not affect the removal efficiencies significantly over a wide range and the effect of changing initial $\mathrm{pH}$ was not significant. This result is in accord with previously published works. ${ }^{(28)}$ Therefore, $\mathrm{pH}$ adjustment before treatment is not required in practical applications. The $\mathrm{pH}$ variation of solution after electrocoagulation process in various voltages showed that the final $\mathrm{pH}$ for all of experiments with iron electrodes is higher than initial $\mathrm{pH}$, and with aluminum electrodes, the final $\mathrm{pH}$ for $\mathrm{pH} 3$ and 7 of experiments is higher than initial $\mathrm{pH}$, but for initial $\mathrm{pH}(\mathrm{pH}=10)$, the final $\mathrm{pH}$ was lower than 10 , which is in agreement with results obtained later. ${ }^{(26,29,30)}$

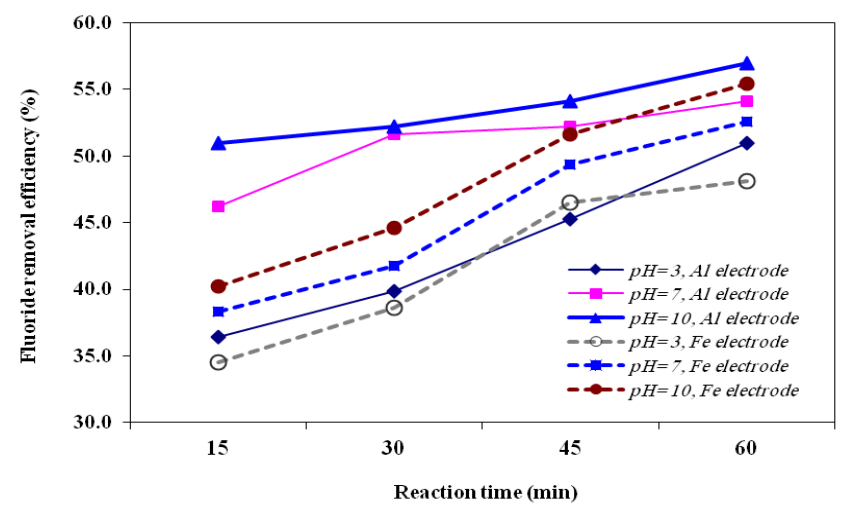

Figure 2. Fluoride Removal as a function of $\mathrm{pH}$ and electrocoagulation time (Initial concentration $=1 \mathrm{mg} \mathrm{L}^{-1}$, Voltage $=10 \mathrm{~V}$ ). 


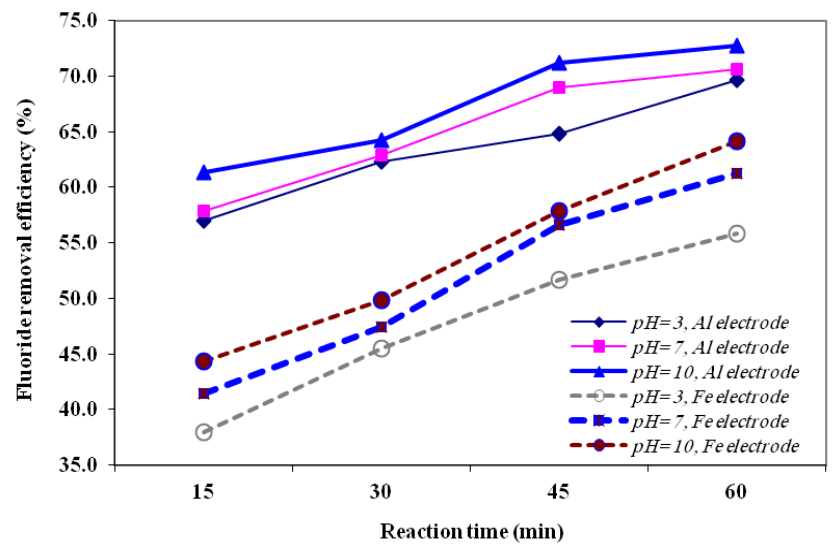

Figure 3. Fluoride Removal as a function of $\mathrm{pH}$ and electrocoagulation time (Initial concentration $=1 \mathrm{mg} \mathrm{L}^{-1}$, Voltage $=20 \mathrm{~V}$ ).

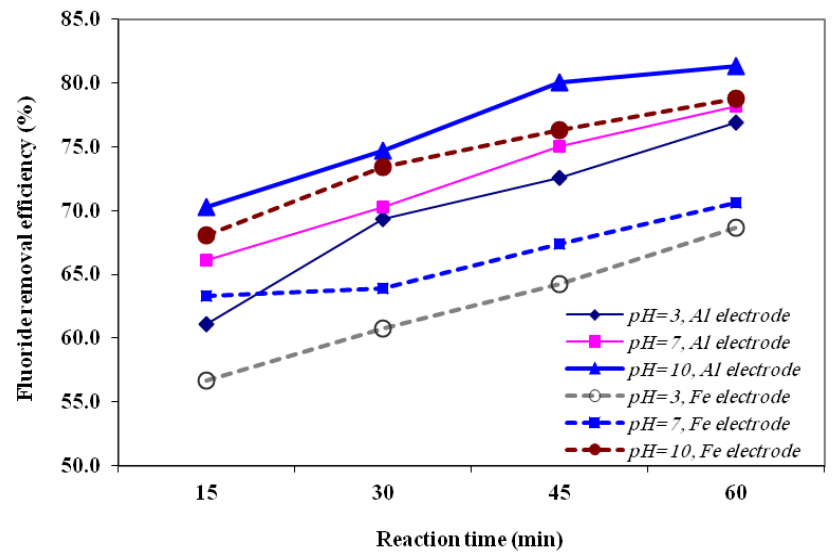

Figure 4. Fluoride Removal as a function of $\mathrm{pH}$ and electrocoagulation time (Initial concentration $=1 \mathrm{mg} \mathrm{L}^{-1}$, Voltage $=30 \mathrm{~V}$ ).

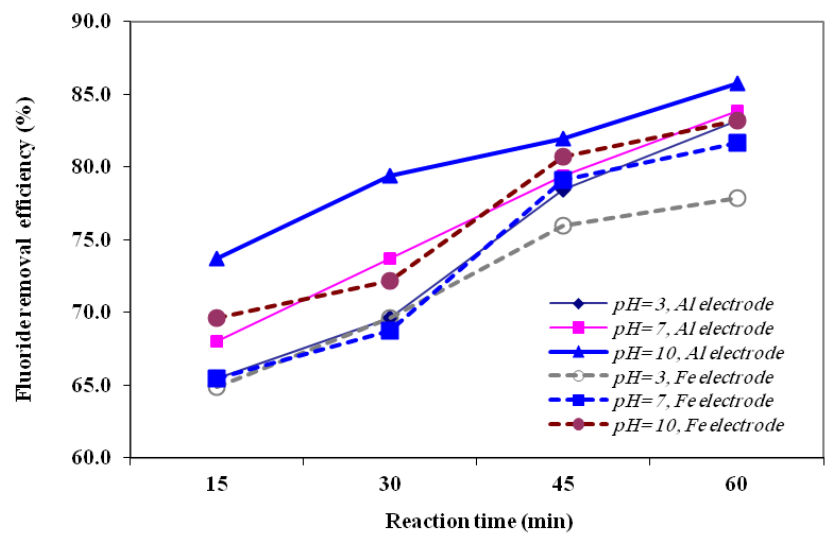

Figure 5. Fluoride Removal as a function of $\mathrm{pH}$ and electrocoagulation time (Initial concentration $=1 \mathrm{mg} \mathrm{L}^{-1}$, Voltage $=40 \mathrm{~V}$ ). 


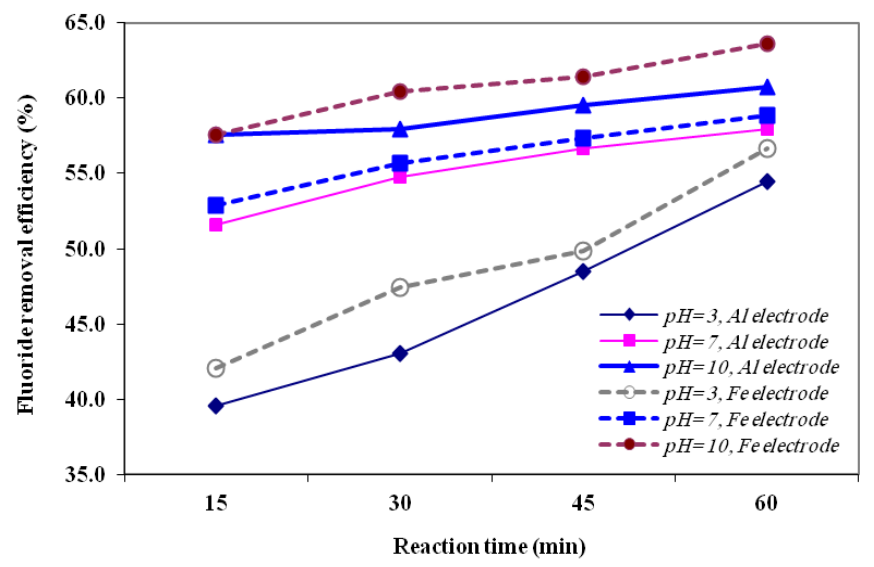

Figure 6. Fluoride Removal as a function of $\mathrm{pH}$ and electrocoagulation time (Initial concentration $=5 \mathrm{mg} \mathrm{L}^{-1}$, Voltage $=10 \mathrm{~V}$ ).

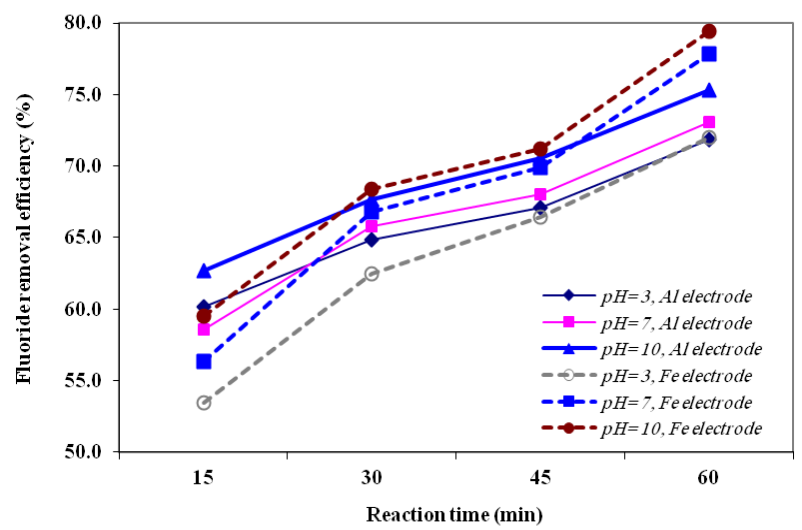

Figure 7. Fluoride Removal as a function of $\mathrm{pH}$ and electrocoagulation time (Initial concentration $=5 \mathrm{mg} \mathrm{L}^{-1}$, Voltage $=20 \mathrm{~V}$ ).

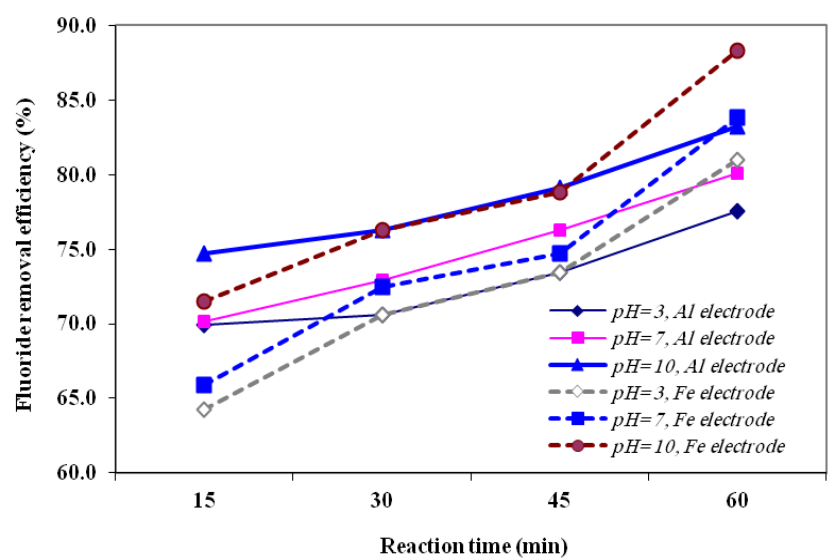

Figure 8. Fluoride Removal as a function of $\mathrm{pH}$ and electrocoagulation time (Initial concentration $=5 \mathrm{mg} \mathrm{L}^{-1}$, Voltage $=30 \mathrm{~V}$ ). 


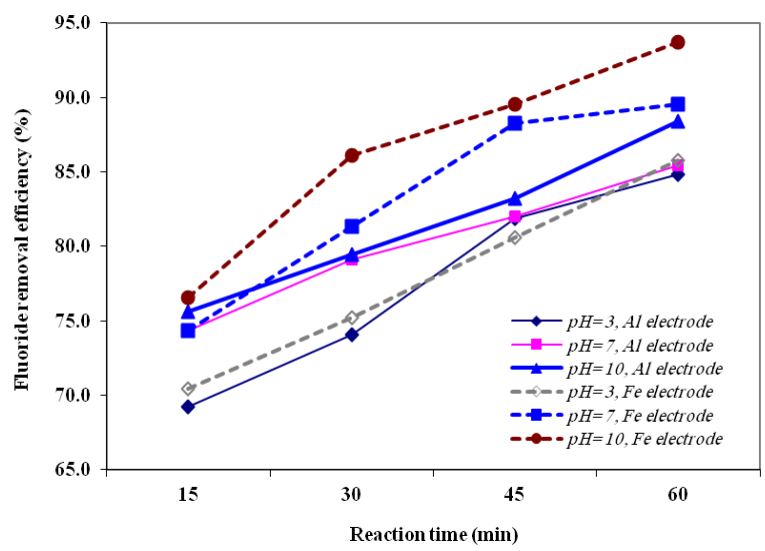

Figure 9. Fluoride Removal as a function of $\mathrm{pH}$ and electrocoagulation time (Initial concentration $=5 \mathrm{mg} \mathrm{L}^{-1}$, Voltage $=40 \mathrm{~V}$ ).

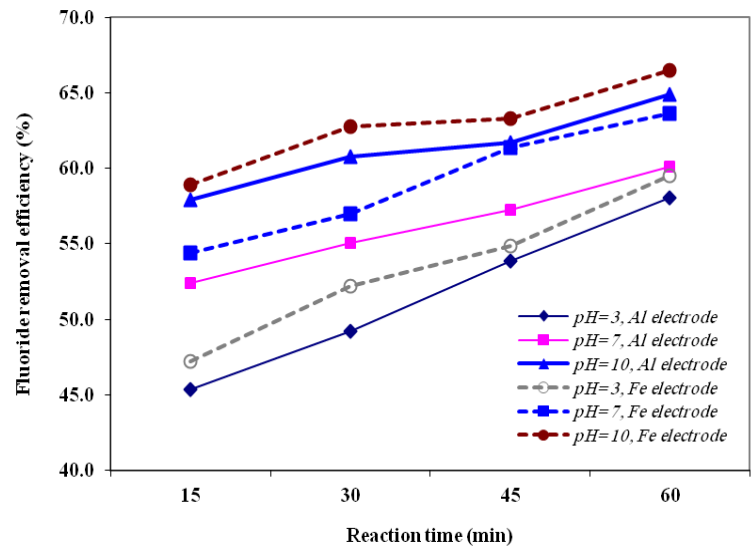

Figure 10. Fluoride Removal as a function of $\mathrm{pH}$ and electrocoagulation time (Initial concentration $=10 \mathrm{mg} \mathrm{L}^{-1}$, Voltage $\left.=10 \mathrm{~V}\right)$.

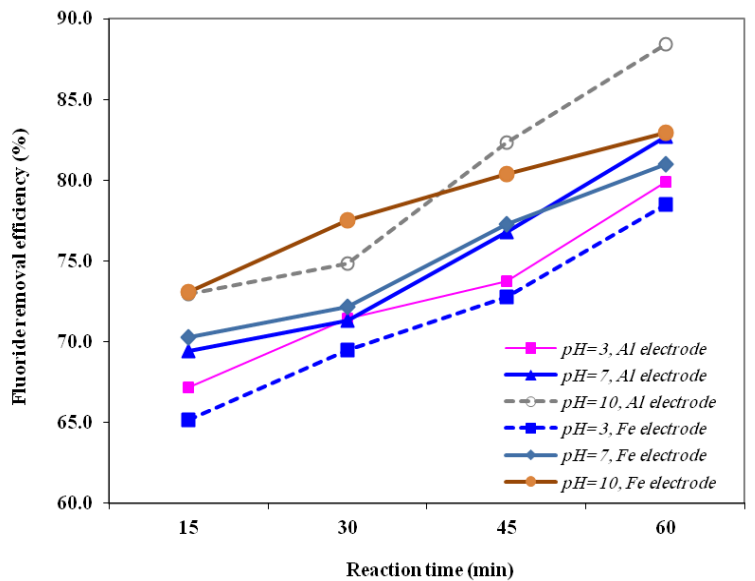

Figure 11. Fluoride Removal as a function of $\mathrm{pH}$ and electrocoagulation time (Initial concentration $=10 \mathrm{mg} \mathrm{L}^{-1}$, Voltage $\left.=20 \mathrm{~V}\right)$. 


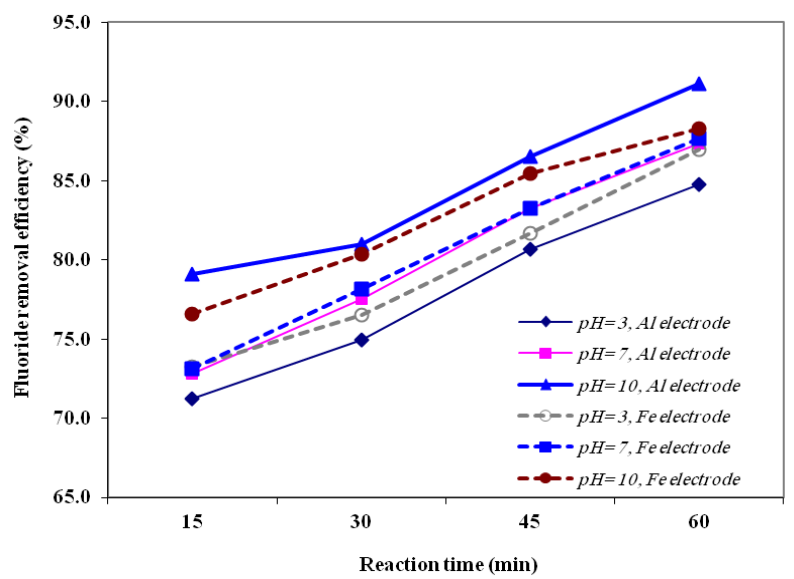

Figure 12. Fluoride Removal as a function of $\mathrm{pH}$ and electrocoagulation time (Initial concentration $=10 \mathrm{mg} \mathrm{L}^{-1}$, Voltage $=30 \mathrm{~V}$ ).

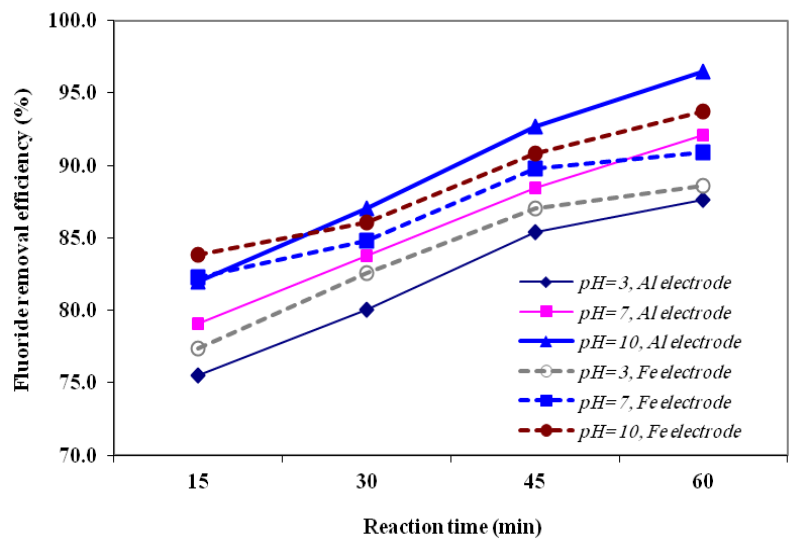

Figure 13. Fluoride Removal as a function of $\mathrm{pH}$ and electrocoagulation time (Initial concentration $=10 \mathrm{mg} \mathrm{L}^{-1}$, Voltage $\left.=40 \mathrm{~V}\right)$.

\section{Effect of applied voltage}

Preliminary laboratory testing of the electrolysis cell involved determining the effect of applied voltage on the efficiency of fluoride removal. It is well-known that electrical current not only determines the coagulant dosage rate but also the bubble production rate and size and the floc growth, ${ }^{(31-32)}$ which can influence the treatment efficiency of the electrocoagulation. Therefore, the effect of current density or applied voltage (electrical potential) on the fluoride removal was investigated. As expected, it appears that for a given time, the removal efficiency increased significantly with the increase in current density. The highest electrical potential $(40 \mathrm{~V})$ produced the quickest treatment with $>65 \%$ reduction occurring after only $15 \mathrm{~min}$ (for all concentrations) and the lowest fluoride removal efficiency occurred in the lowest electrical potential $(10 \mathrm{~V})$ and initial concentrations of 1.0 $\mathrm{mg} \mathrm{L}^{-1}$. This is ascribed to the fact that at higher voltage the amount of Iron oxidized increased, resulting in a greater amount of precipitate for the removal of pollutants. In addition, it was demonstrated that bubbles density increases and their size decreases with increasing current density, ${ }^{(26,30,33)}$ resulting in a greater upwards flux and a faster removal of 
pollutants and sludge flotation. As the current decreased, the time needed to achieve similar efficiencies increased and the results of this research confirm this fact. This expected behavior is explained by the fact that the treatment efficiency was mainly affected by charge loading $(\mathrm{Q}=\mathrm{It})$, as reported by Chen et al. ${ }^{(27)}$ However, the cost of the process is determined by the consumption of the sacrificial electrode and the electrical energy which economically are the advantages of this method. These results suggest $40 \mathrm{~V}$ as an optimal electrical potential for the treatment of effluents containing fluoride, since it ensures the quickest removal rate with the lowest cost.

\section{Effect of initial concentration of fluoride ion}

A set of experiments was performed with different initial concentrations of fluoride to determine the time required for removal under various conditions of electrocoagulation process. The results obtained at different electrical potential showed that initial concentration of fluoride cannot effect significantly on efficiency removal and for higher concentration of fluoride, lower electrical potential is needed. On the other hand, there is not a direct correlation between pollutant concentration and removal efficiency. It is clear from figures (2-13) that in the higher concentrations, longer time is needed for removal of fluoride, but higher initial concentrations of fluoride were reduced significantly in relatively less time than lower concentrations. This can be explained by the theory of dilute solution. In dilute solution, formation of the diffusion layer at the vicinity of the electrode causes a slower reaction rate, but in concentrated solution the diffusion layer has no effect on the rate of diffusion or migration of metal ions to the electrode surface. ${ }^{(34,35,36)}$

\section{Effect of reaction time}

The time dependence of fluoride removal by electrocoagulation process at different $\mathrm{pHs}$ is shown in figures $2-13$. It can be seen from the figures that up to $30-85 \%$ of the initial concentration of fluoride decreased within 15-30 min of processing for all concentrations and the residual fluoride concentration in effluent at the end of reaction time $(60 \mathrm{~min})$ reached to $<1.0 \mathrm{mg} \mathrm{L}^{-1}$ so we can discharge treated effluents to the environment in safety. Comparison of fluoride removal efficiency (figures 2-13) showed that removal efficiency is similar with iron and aluminum electrodes.

\section{Energy and electrode consumption}

With regard to a series of tests conducted with different concentration of fluoride in the solution, the weight of the electrode consumed with respect to different voltage of the pilot under study are given in Tables 1 and 2 for iron and aluminum electrodes, respectively. As it is presented in the Tables, electrode consumption varied between 0.36 and $2.31 \mathrm{~g} \mathrm{~L}^{-1}$ for iron electrodes and 0.29 and $1.67 \mathrm{~g} \mathrm{~L}^{-1}$ for aluminum electrodes. It can be concluded that the higher voltage of the system applied, the weight of the electrode consumed in the process has been increased and also the higher the concentrations of the fluoride in the solution, the higher consumption of the electrode is would be. As the Tables represents the electrode consumed with 40 volts in the process is much more than the process conducted with 10 volts. As the fluoride concentration in the solution increased to $10 \mathrm{mg} \mathrm{L}^{-1}$, the consumption of the electrode did not increase as much, but the fluoride removal efficiency has taken place, because much floc formation helped to sweep away fluoride and there was no need for as much electrode consumption as before.

The relationship between the electrical energy consumption and fluoride concentration are presented in Tables 3 and 4 for iron and aluminum electrodes, respectively. The energy consumption varied between 0.0008 and $0.0336 \mathrm{KWh} \mathrm{g}^{-1}$ with iron electrodes and 0.000775 
and $0.0349 \mathrm{KWh} \mathrm{g}^{-1}$ with aluminum electrodes. It can be concluded that the consumed energy for iron and aluminum electrodes are similar.

Table 1. Iron electrode consumption during electrocoagulation process $\left(\mathrm{g} \mathrm{L}^{-1}\right)$.

\begin{tabular}{cccccccccc}
\hline & \multicolumn{2}{c}{$\begin{array}{c}\text { F Concentration }=1.0 \\
\mathrm{mg} \mathrm{L}\end{array}$} & \multicolumn{3}{c}{$\begin{array}{c}\text { F Concentration }=5.0 \\
\mathrm{mg} \mathrm{L}^{-1}\end{array}$} \\
\cline { 2 - 11 } $\begin{array}{c}\text { Voltage } \\
\text { V) }\end{array}$ & \multicolumn{3}{c}{ Initial pH } & \multicolumn{3}{c}{$\begin{array}{c}\text { F Concentration }=10.0 \\
\mathrm{mg} \mathrm{L}^{-1}\end{array}$} \\
\cline { 2 - 11 } & 3.0 & 7.0 & 10.0 & 3.0 & 7.0 & 10.0 & 3.0 & 7.0 & 10.0 \\
\hline 10 & 0.36 & 0.57 & 0.58 & 0.39 & 0.51 & 0.56 & 0.73 & 0.51 & 0.58 \\
\hline 20 & 0.85 & 1.02 & 1.19 & 0.94 & 1.28 & 1.41 & 1.42 & 0.74 & 0.79 \\
\hline 30 & 1.16 & 1.34 & 1.51 & 1.35 & 1.57 & 1.59 & 1.17 & 1.22 & 1.37 \\
\hline 40 & 2.31 & 1.94 & 2.13 & 1.92 & 1.63 & 1.71 & 1.45 & 1.75 & 1.87 \\
\hline
\end{tabular}

Table 2. Aluminum electrode consumption during electrocoagulation process $\left(\mathrm{g} \mathrm{L}^{-1}\right)$.

\begin{tabular}{|c|c|c|c|c|c|c|c|c|c|}
\hline \multirow{3}{*}{$\begin{array}{l}\text { Voltage } \\
\text { (V) }\end{array}$} & \multicolumn{3}{|c|}{$\begin{array}{l}\text { F Concentration }=1.0 \mathrm{mg} \\
\mathrm{L}^{-1}\end{array}$} & \multicolumn{3}{|c|}{$\begin{array}{c}\text { F Concentration }=5.0 \\
\mathrm{mg} \mathrm{L}^{-1}\end{array}$} & \multicolumn{3}{|c|}{$\begin{array}{c}\text { F Concentration }=10.0 \\
\mathrm{mg} \mathrm{L}^{-1}\end{array}$} \\
\hline & \multicolumn{3}{|c|}{ Initial $\mathrm{pH}$} & \multicolumn{3}{|c|}{ Initial $\mathrm{pH}$} & \multicolumn{3}{|c|}{ Initial pH } \\
\hline & 3.0 & 7.0 & 10.0 & 3.0 & 7.0 & 10.0 & 3.0 & 7.0 & 10.0 \\
\hline 10 & 0.32 & 0.51 & 0.63 & 0.29 & 0.64 & 0.73 & 0.61 & 0.55 & 0.67 \\
\hline 20 & 0.45 & 0.66 & 0.71 & 0.61 & 0.82 & 0.86 & 0.76 & 0.64 & 0.75 \\
\hline 30 & 0.57 & 0.84 & 0.87 & 0.78 & 0.88 & 0.95 & 0.95 & 0.89 & 0.98 \\
\hline 40 & 0.64 & 1.22 & 1.29 & 1.53 & 1.67 & 1.26 & 1.28 & 1.23 & 1.46 \\
\hline
\end{tabular}

Table 3. Electrical energy consumption during electrocoagulation process $\left(\mathrm{kWh} \mathrm{g}^{-1}\right)$ using iron electrodes.

\begin{tabular}{|c|c|c|c|c|c|c|c|c|c|}
\hline \multirow{3}{*}{$\begin{array}{c}\text { Volta } \\
\text { ge } \\
\text { (V) }\end{array}$} & \multicolumn{3}{|c|}{$\begin{array}{c}\text { F Concentration }=1.0 \mathrm{mg} \\
\mathrm{L}^{-1}\end{array}$} & \multicolumn{3}{|c|}{$\begin{array}{c}\text { F Concentration }=5.0 \mathrm{mg} \\
\mathrm{L}^{-1}\end{array}$} & \multicolumn{3}{|c|}{$\begin{array}{c}\text { F Concentration }=10.0 \\
\mathrm{mg} \mathrm{L}^{-1}\end{array}$} \\
\hline & \multicolumn{3}{|c|}{ Initial $\mathrm{pH}$} & \multicolumn{3}{|c|}{ Initial $\mathrm{pH}$} & \multicolumn{3}{|c|}{ Initial $\mathrm{pH}$} \\
\hline & 3.0 & 7.0 & 10.0 & 3.0 & 7.0 & 10.0 & 3.0 & 7.0 & 10.0 \\
\hline \multirow{2}{*}{10} & 0.00 & 0.0013 & 0.0012 & 0.0010 & \multirow{2}{*}{0.0015} & 0.0012 & 0.0010 & 0.001 & 0.0015 \\
\hline & 08 & 25 & 5 & 25 & & 25 & 75 & 45 & 5 \\
\hline \multirow{2}{*}{20} & 0.00 & 0.0057 & 0.0070 & \multirow{2}{*}{0.0056} & 0.0068 & 0.0070 & \multirow{2}{*}{0.0061} & 0.006 & 0.0068 \\
\hline & 48 & 5 & 5 & & 5 & 5 & & 6 & 5 \\
\hline \multirow{2}{*}{30} & 0.01 & 0.0111 & 0.0132 & 0.0116 & 0.0140 & \multirow{2}{*}{0.0147} & 0.0125 & 0.014 & 0.0150 \\
\hline & 02 & 75 & 75 & 25 & 25 & & 25 & 55 & 75 \\
\hline 40 & $\begin{array}{c}0.02 \\
13\end{array}$ & 0.0242 & 0.0314 & 0.0252 & 0.03 & 0.0329 & 0.0304 & $\begin{array}{c}0.032 \\
6\end{array}$ & 0.0336 \\
\hline
\end{tabular}


Table 4. Electrical energy consumption during electrocoagulation process ( $\left.\mathrm{kWh} \mathrm{g}^{-1}\right)$ using aluminum electrodes.

\begin{tabular}{ccccccccccc}
\hline \multirow{2}{*}{$\begin{array}{c}\text { Volta } \\
\text { ge }\end{array}$} & \multicolumn{3}{c}{$\begin{array}{c}\text { F Concentration }=1.0 \mathrm{mg} \\
\mathrm{L}^{-1}\end{array}$} & \multicolumn{3}{c}{ Initial $\mathrm{pH}$} & \multicolumn{3}{c}{$\begin{array}{c}\text { F Concentration }=5.0 \\
\mathrm{mg} \mathrm{L}^{-1}\end{array}$} & \multicolumn{3}{c}{$\begin{array}{c}\text { F Concentration }=10.0 \\
\mathrm{mg} \mathrm{L}^{-1}\end{array}$} \\
\cline { 2 - 11 } (V) & 3.0 & 7.0 & 10.0 & 3.0 & 7.0 & 10.0 & 3.0 & 7.0 & 10.0 \\
\hline 10 & 0.0007 & 0.001 & 0.0012 & 0.0009 & 0.00 & 0.0015 & 0.001 & 0.001 & 0.0014 \\
& 75 & 25 & 5 & 5 & 16 & 25 & & 25 & 5 \\
\hline 20 & 0.0037 & 0.007 & 0.0049 & 0.0053 & 0.00 & 0.0057 & 0.0061 & 0.005 & 0.0052 \\
& 5 & 95 & 5 & 5 & 52 & 5 & 5 & 05 & 5 \\
\hline 30 & 0.0115 & 0.019 & 0.0159 & 0.0116 & 0.01 & 0.0145 & 0.0162 & 0.013 & 0.0147 \\
& 5 & 2 & 75 & 25 & 65 & 5 & 75 & 05 & 75 \\
\hline 40 & 0.0217 & 0.031 & 0.0295 & 0.0249 & 0.03 & 0.0306 & 0.029 & 0.024 & 0.0278 \\
\hline
\end{tabular}

\section{Conclusion}

The present study attempted to investigate the applicability of an electrocoagulation method using iron and aluminum electrodes in the removal of fluoride from aqueous environments. The influence of various variables such as $\mathrm{pH}$, reaction time, and conductivity of solution on the removal of fluoride was investigated. The results showed that electrocoagulation process with iron and aluminum electrodes could successfully remove fluoride from the aqueous environments. The results obtained with synthetic solutions revealed that the increase of reaction time, in the range of $0-60 \mathrm{~min}$, enhanced the treatment rate for both iron and aluminum electrodes. The maximum efficiency of fluoride removal for various initial concentration of fluoride was obtained in constant electrolysis voltage of $40 \mathrm{~V}$ and reaction time of $60 \mathrm{~min}$. Finally, the results demonstrated the technical feasibility of electrocoagulation as a reliable technique for removal of fluoride from aqueous environments.

\section{Acknowledgement}

This study was funded by the health research deputy of Zahedan University of Medical Sciences (Project Number, 88-2037) and was conducted in the Chemical Laboratory of School of Public Health, Zahedan University of Medical Sciences.

\section{References}

1. Viswanathan G, Jaswanth A, Gopalakrishnan S, Siva ilango S and Aditya G. Science of the Total environment, 2009, 407(20), 5298.

2. Burgstahler AW, Fluoride, 2006, 39, 252.

3. Shivarajashankara Y M, Shivashankara A R, Rao SH and Bhar PG, Fluoride, 2001, 34, 103.

4. Spittle B, Fluoride, 2008, 41, 89 .

5. Carton R J, Fluoride, 2006, 39, 163.

6. Dobaradaran S, Mahvi A H, Dehdashti S, Ranjbar D and Abadia V, Fluoride, 2008, 41(3), 220. 
7. Hu C Y, Lo S L, Kuan W H and Lee Y D, Water Research, 2005, 39, 895.

8. Pehrsson P R, Perry C R, Cutrufelli R C, Patterson K Y, Wilger J, Haytowitz D B, Holden J M, Day C D, Himes J H, Harnack L, Levy S, Wefel J, Heilman J, Phillips K M and Rasor A S, Journal of Food Composition and Analysis, 2006, 19, S45.

9. Nemerow N L, Agardy F J, Sullivan P and Salvato JA. Environmental engineering, water, wastewater, soil and ground water treatment and remediation, 6th Edition, 2326, 2009.

10. Dobaradaran S, Fazelinia F, Mahvi A H, Hosseini S, Fluoride, 2009, 42, 228.

11. Dobaradaran S, Mahvi A H, Dehdashti S, Dobaradaran S and Shoara L, Fluoride, 2009, 42, 50 .

12. Nouri J, Mahvi A H, Babaei A A and Ahmadpour E, Fluoride, 2006, 39, 321.

13. Mahvi A H, Zazoli M A, Younecian M, Nicpour B and Babapour A, Journal of Medical Sciences, 2006, 6, 658.

14. Dobaradaran S, Mahvi A H and Dehdashti S, Fluoride, 2008, 41, 93.

15. Mahvi A H, Zazoli M A, Younecian M and Esfandiari Y, Fluoride, 2006, 39, 266.

16. Niam M F, Othman F, Sohaili J and Fauzia Z, Water Sci. Tech, 2007, 56 (7), 47.

17. Schulz M C, Baygents J C, Farrell. Laboratory and pilot testing of electrocoagulation for removing scale-forming species from industrial process waters. Int. J. Environ. Sci. Tech. 2009, 6 (4), 526.

18. Karbassi A R, Nouri J and Ayaz G O, Int. J. Environ. Res, 2007, 1(1), 66.

19. Cenkin V E and Belevstev A N, Eff. Water Treat. J, 1985, 25 (7), 243.

20. American Public Health Association (APHA). Standard method for the examination of water and wastewater. 18th Edition, APHA, AWWA., WEF, USA.1992.

21. Chen X, Chen G and Po L Y, Sep. Purif. Technol, 2000, 9, 65.

22. Adhoum N, Monser L, Bellakhal N and Belgaied J E, J. Hazardous Mater, 2004, B112, 207.

23. Bayramoglu M, Kobya M, Can O T and Sozbir M, Sep. Purfi. Technol, 2004, 37, 117.

24. Vik E A, Carlson D A, Eikum A S and Gjessing E T, Water Res, 1984, 18, 1355.

25. Yao Hua Ch, Lien Loa Sh, Kuan W H and Lee Y D, Sep. Purif. Technol, 2008, 60, 1.

26. Bazrafshan E, Mahvi A H, Nasseri S and Shaighi M, Iran. J. Environ. Health. Sci. Eng, 2007, 2(4), 127.

27. Chen X, Chen G and Po L Y, Sep. Purif. Technol, 2000, 9, 65.

28. Phalakornkule Ch, Polgumhang S, Tongdaung W, Karakat B and Nuyut Th, J. Environ Management, 2010, 91, 918.

29. Kobya M, Taner Can O and Bayramoglu M, J. Hazardous Mater, 2003, B100, 163.

30. Bazrafshan E, Mahvi A H, Naseri S and Mesdaghinia A R, Turkish J. Eng. Environ. Sci, 2008, 32 (2), 59.

31. Letterman R D, Amirtharajah A and O'Melia C R, Chapter 6, Coagulation and flocculation, in, Water quality and treatment, $5^{\text {th }}$., AWWA, McGraw-Hill., New York, 1999.

32. Holt P H, Barton G W, Wark M and Mitchell A A, Colloids Surf. A: Physicochem. Eng. Aspects, 2002, 211, 233.

33. Khosla N K, Venkachalam S and Sonrasundaram P, J. Appl. Electrochem, 1991, 21, 986.

34. Chaudhary A. J, Goswami N. C and Grimes S M, J. Chem. Tech. Biotech, 2003,78, 877.

35. Nouri J, Mahvi A H and Bazrafshan E, J Environ Res, 2010, 4(2), 201.

36. Bazrafshan E, Zazouli M A and Mahvi A H, Asian Journal of Chemistry, 2011, 23 (12), 5506. 


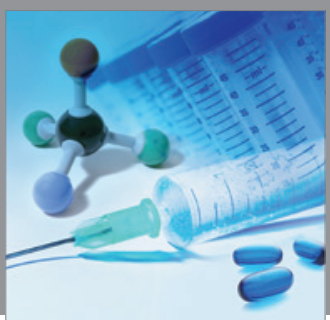

International Journal of

Medicinal Chemistry

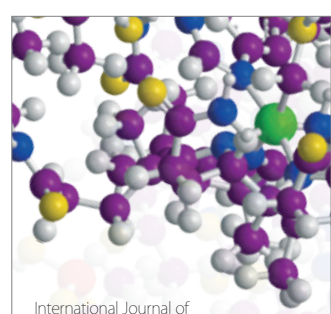

Carbohydrate Chemistry

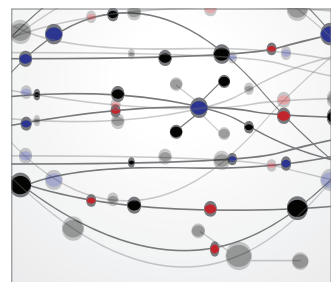

The Scientific World Journal
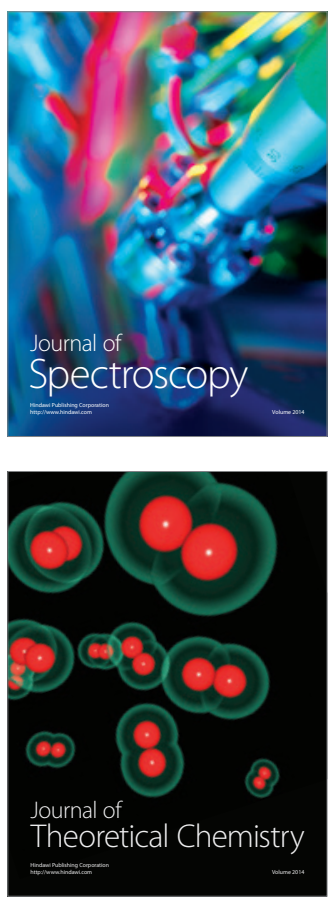
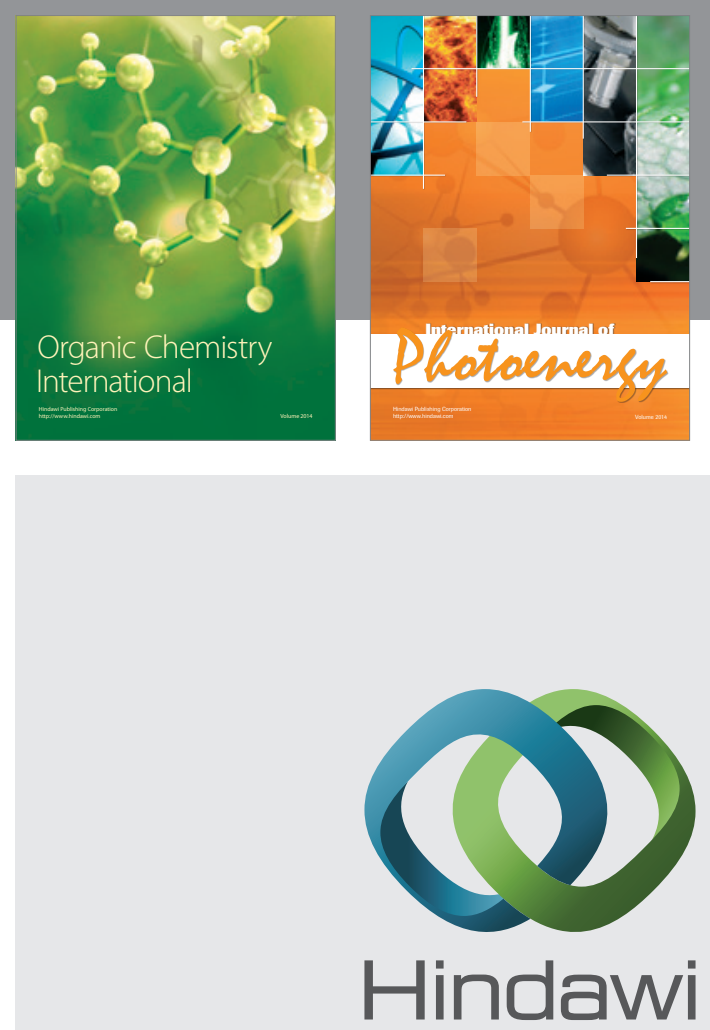

Submit your manuscripts at

http://www.hindawi.com
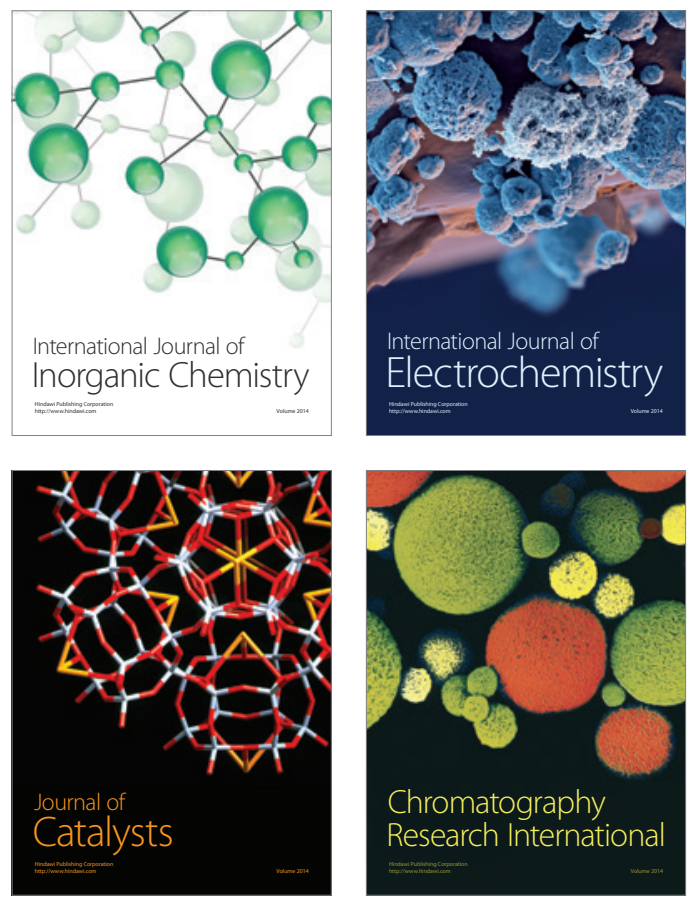
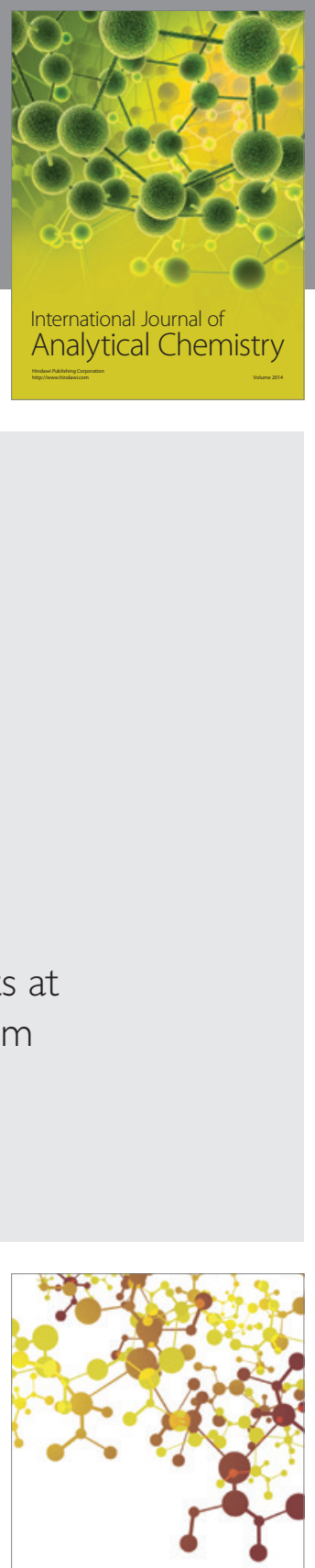

Journal of

Applied Chemistry
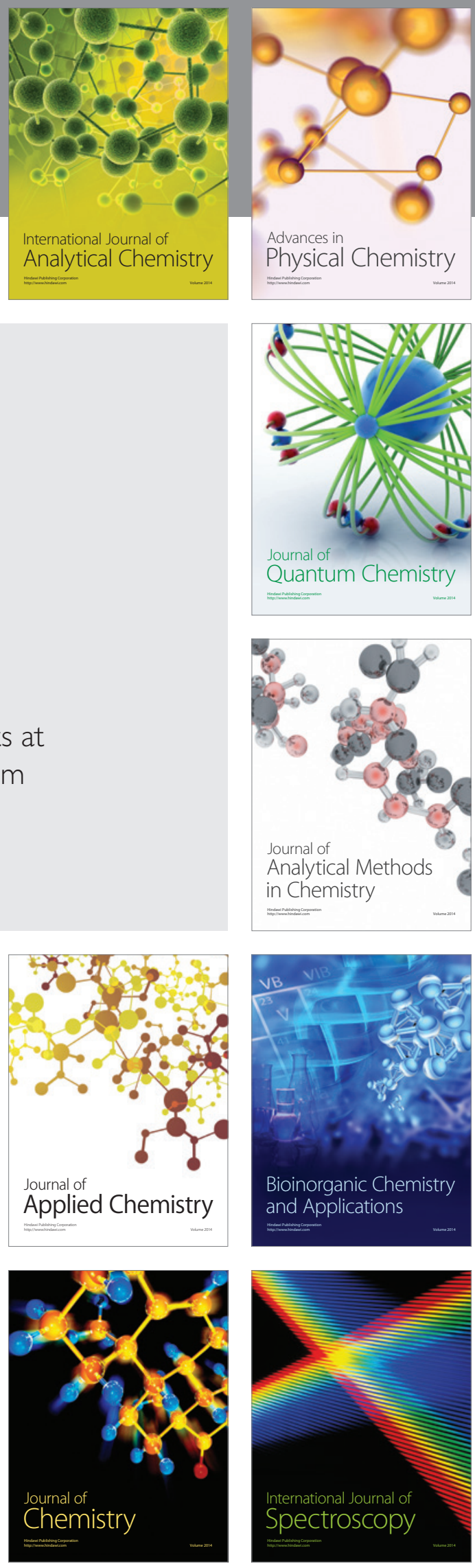